\title{
Tyrosine-protein phosphatase non-receptor type 12 expression is a good prognostic factor in resectable non-small cell lung cancer
}

\author{
Xun Cao ${ }^{1, *}$, Yan-Zhen Chen ${ }^{1, *}$, Ruo-Zhen Luo ${ }^{1,2}$, Lin Zhang ${ }^{1,3}$, Song-Liang Zhang ${ }^{1,5}$, \\ Jun Zeng ${ }^{1,5}$, Yu-Chuan Jiang ${ }^{1,5}$, Yu-Jing Han ${ }^{1,4}$ and Zhe-Sheng Wen ${ }^{1,5}$ \\ ${ }^{1}$ Sun Yat-Sen University Cancer Center, State Key Laboratory of Oncology in South China, Collaborative Innovation Center \\ of Cancer Medicine, Guangzhou, Guangdong, China \\ 2 Department of Pathology, Sun Yat-Sen University Cancer Center, Guangzhou, Guangdong, China \\ ${ }^{3}$ Department of Clinical Laboratory, Sun Yat-Sen University Cancer Center, Guangzhou, Guangdong, China \\ ${ }^{4}$ Department of Preclinical Medicines, Sun Yat-Sen University Cancer Center, Guangzhou, Guangdong, China \\ ${ }^{5}$ Department of Thoracic Oncology, Sun Yat-Sen University Cancer Center, Guangzhou, Guangdong, China \\ * These authors contribute equally to this work \\ Correspondence to: Zhe-Sheng Wen, email: dr_wenshesheng@yahoo.com
}

Keywords: non-small cell lung cancer, tyrosine-protein phosphatase non-receptor type 12, survival, prognosis

Received: January 06, $2015 \quad$ Accepted: February 19, $2015 \quad$ Published: March 14, 2015

This is an open-access article distributed under the terms of the Creative Commons Attribution License, which permits unrestricted use, distribution, and reproduction in any medium, provided the original author and source are credited.

\section{ABSTRACT}

Tyrosine-protein phosphatase non-receptor type 12 (PTPN12) has been considered to be a tumor suppressor in human cancer, but its clinical and prognostic significance in non-small cell lung cancer (NSCLC) has not been well elucidated.

A retrospective analysis of $\mathbf{2 1 5}$ patients with surgically resected NSCLCs from Sun Yat-Sen University Cancer Center between April 2002 and March 2005 was performed using immunohistochemistry and Western Blot to analyze PTPN12 expression. The association between PTPN12 expression and patient survival was investigated.

Western Blots showed that the expression level of PTPN12 were higher in normal paracancerous lung tissues than in NSCLC tissues. High PTPN12 expression was less common in the presence than in the absence of visceral pleural invasion $(p=0.038)$. Patients with PTPN12-high tumors had a longer disease-free survival (DFS) $(P<0.001)$ and overall survival $(O S)(p<0.001)$, especially for those with non-squamous cell carcinoma (non-SCC) (DFS, $\mathrm{p}<0.001 ; 0 S, \mathrm{p}<0.001$ ). Multivariate analysis confirmed that PTPN12 positivity was associated with increased survival duration (DFS, $\mathrm{p}<0.001$; OS, $p<0.001$ ), independent of prognostic indicator.

High PTPN12 expressive levels are associated with favorable survival duration in patients with NSCLC, especially those with non-SCC. Our study suggests that PTPN12 expression is a valuable prognostic biomarker for NSCLC patients.

\section{INTRODUCTION}

Lung cancer continue to be the most common causes of cancer death worldwide [1]. Patients with non-small cell lung cancer (NSCLC), which account for 75\%-80\% of lung cancer cases, carry a 5-years survival rate of $10 \%$ $15 \%$ for all stage. Curative-intent resection remains the mainstay of treatment and provides the best chance for survival [2]. Unfortunately, however, many patients with the same pathological Tumor-Node-Metastasis (TNM) stage have different survivals. Thus, the American Joint Committee on Cancer Staging system (AJCC) may be not reliable to predict clinical outcomes. Studies conducted several years ago have suggested that cancer has been envisioned as a signaling disease [3]. A better understanding of the biochemical signaling molecules and genetic factors of NSCLC could provide valuable prognostic parameter, improve the prognoses of patients and provide therapies that are more appropriate [4-7].

Protein tyrosine phosphatases (PTPs) are a 
group of enzymes that remove phosphate groups from phosphorylated tyrosine residues on proteins. In the past few years, several investigations implicated that PTPs are key regulatory components in signal transduction pathways, such as the MAP kinase pathway, and are important in the control of cell growth, cellular proliferation, cellular differentiation, mitotic cycles and oncogenic transformation [8-11]. Sun et al. have recently uncovered a new molecular biomarker, TyrosineProtein Phosphatase Non Receptor Type 12 (PTPN12), which is a member of the PTPs family [12]. PTPN12 can suppress cell proliferation and tumorigenicity by inhibiting multiple receptor tyrosine kinases (RTKs). RTKs regulate cell survival and proliferation and signal via autophosphorylation and recruitment of additional substrates through recognition of these autophosphorylation sites [9]. Activation of PTPN12 suppresses RTKs, leading to inhibition of cell growth, proliferation, transformation and tumorigenesis through downstream signaling. These functions implied that PTPN12 play a prominent role in tumor suppression.

However, the role of PTPN12 and the association between PTPN12 and survival in NSCLC have not been rigorously and systematically elucidated. Based on these considerations, the primary aim of the current study was to identify the expression of PTPN12 in NSCLC samples in a large patients cohort. In addition, the overarching goal of this research is to discuss the clinicopathological and predictive value of PTPN12 expression in NSCLC patients.

(A)
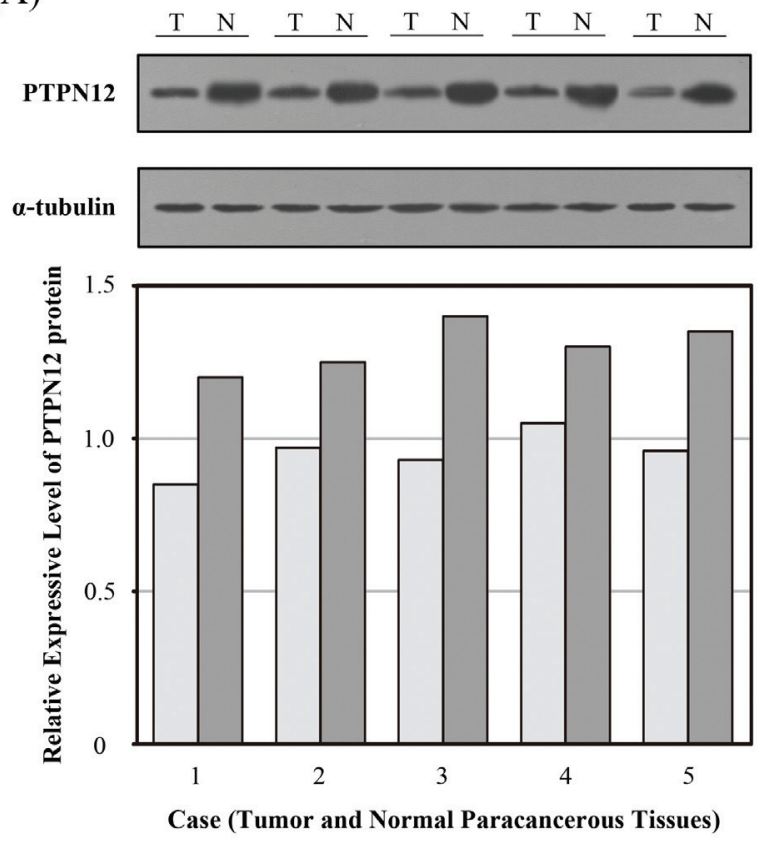

\section{RESULTS}

\section{Patient characteristics}

After exclusion of the non-informative samples (unrepresentative samples, samples with too few tumor cells and lost samples), PTPN12 expression was evaluated in a total of $215(89.6 \%)$ patients. All further statistical analyses were performed on this population.

The median age of the patients was 60 years (range, 30 to 79 years), and $74.4 \%$ were men. Of 215 NSCLC patients, $76(35.3 \%)$ had squamous cell carcinoma (SCC), and $139(64.7 \%)$ had non-SCC. Table 1 summarizes the characteristics of the study population.

\section{Western blot assessment of PTPN12 expression}

In order to ensure the reliability of this study, we first investigated the expression level of PTPN12 protein by Western blot in 10 pairs of surgically resected lung tissues. The relative PTPN12 expression was compared in NSCLC tissues and normal paracancerous tissues. Western blot analysis showed that the PTPN12 protein expression was higher in normal paracancerous tissue than in NSCLC tissues (figure 1).

(B)
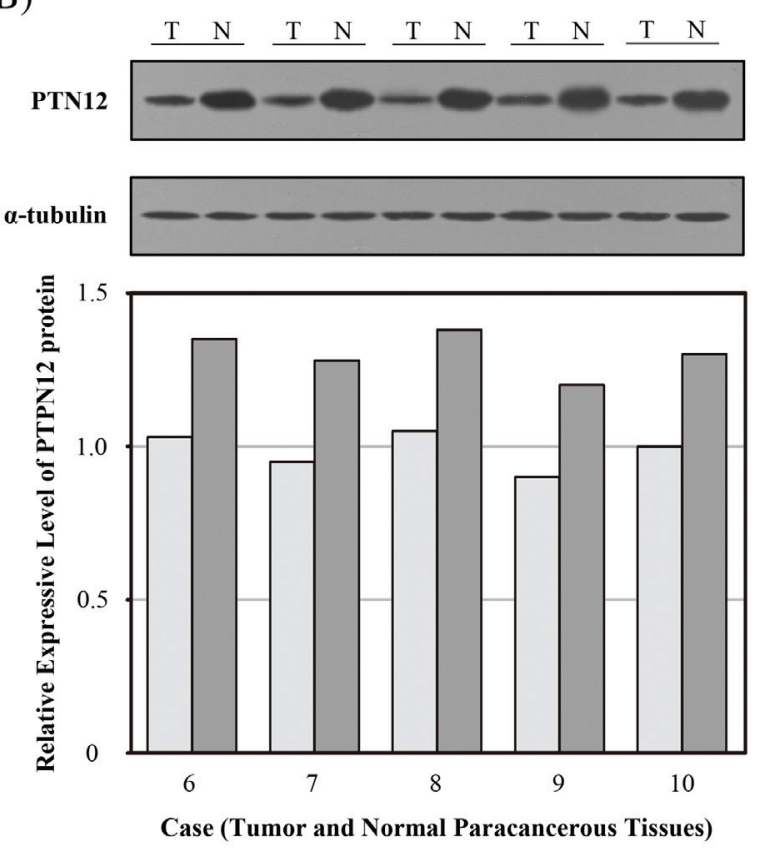

Figure 1: Expression of tyrosine-protein phosphatase non-receptor type 12 (PTPN12) in surgically resected lung tissues was determined by Western blot. Expression of PTPN12 in normal paracancerous tissues and non-small cell lung cancer (NSCLC) tissues. The relative expression of PTPN12 in comparison to the expression level of $\alpha$-tubulin. (A) Case 1-5; (B) Case 6-10. (T, tumor tissue; $\mathrm{N}$, normal parecancerous tissue). 
Table 1: PTPN12 expression and clinicopathological characteristics of the patients with NSCLCs

\begin{tabular}{|c|c|c|c|c|}
\hline \multirow[b]{2}{*}{ Characteristic } & \multirow{2}{*}{$\begin{array}{l}\text { No. Patients } \\
(\%)\end{array}$} & \multicolumn{2}{|c|}{ PTPN12 expression (\%) } & \multirow[b]{2}{*}{ p Value ${ }^{a}$} \\
\hline & & Low & High & \\
\hline Total & 215 & $109(50.7)$ & $106(49.3)$ & \\
\hline Age (years) ${ }^{b}$ & & & & 0.090 \\
\hline$\leq 60$ & $114(53.0)$ & $64(56.1)$ & $50(43.9)$ & \\
\hline$>60$ & $101(47.0)$ & $45(44.6)$ & $56(55.4)$ & \\
\hline Gender & & & & 0.556 \\
\hline Male & $160(74.4)$ & $83(51.9)$ & $77(48.1)$ & \\
\hline Female & $55(25.6)$ & $26(47.3)$ & $29(52.7)$ & \\
\hline Tumor laterality & & & & 0.792 \\
\hline Left & $81(37.7)$ & $42(51.9)$ & $39(48.1)$ & \\
\hline Right & $134(62.3)$ & $67(50.0)$ & $67(50.0)$ & \\
\hline Primary lobe & & & & 0.055 \\
\hline Upper lobe & $102(47.4)$ & $43(42.2)$ & $59(57.8)$ & \\
\hline Middle lobe & $21(9.8)$ & $13(61.9)$ & $8(38.1)$ & \\
\hline Lower lobe & $92(42.8)$ & $53(57.6)$ & $39(42.4)$ & \\
\hline Histology & & & & 0.662 \\
\hline $\mathrm{SCC}$ & $76(35.3)$ & $37(48.7)$ & $39(51.3)$ & \\
\hline Non-SCC ${ }^{\mathrm{c}}$ & $139(64.7)$ & $72(51.8)$ & $67(48.2)$ & \\
\hline Visceral pleural invasion & & & & 0.038 \\
\hline Absent & $63(29.3)$ & $25(39.7)$ & $38(60.3)$ & \\
\hline Present & $152(70.7)$ & $84(55.3)$ & $68(44.7)$ & \\
\hline Tumor grade & & & & 0.264 \\
\hline Grade 1 & $28(13.0)$ & $18(64.3)$ & $10(35.7)$ & \\
\hline Grade 2 & $88(40.9)$ & 41 (46.6) & $47(53.4)$ & \\
\hline Grade 3 & $99(46.0)$ & $50(50.5)$ & $49(49.5)$ & \\
\hline pT status & & & & 0.191 \\
\hline pT1 & $39(18.1)$ & $15(38.5)$ & $24(61.5)$ & \\
\hline pT2 & $150(69.8)$ & $81(54.0)$ & $69(46.0)$ & \\
\hline pT3 & $19(8.8)$ & $8(42.1)$ & $11(57.9)$ & \\
\hline pT4 & $7(3.3)$ & $5(71.4)$ & $2(28.6)$ & \\
\hline $\mathrm{pN}$ status & & & & 0.226 \\
\hline pN0 & $115(53.5)$ & $52(45.2)$ & $63(54.8)$ & \\
\hline $\mathrm{pN} 1$ & $44(20.5)$ & $25(56.8)$ & $19(43.2)$ & \\
\hline $\mathrm{pN} 2$ & $56(26.0)$ & $32(57.1)$ & $24(42.9)$ & \\
\hline pTNM stage & & & & 0.038 \\
\hline I & $86(40.0)$ & $35(40.7)$ & $51(59.3)$ & \\
\hline II & $67(31.2)$ & $41(61.2)$ & $26(38.8)$ & \\
\hline III & $62(28.8)$ & $33(53.2)$ & $29(46.8)$ & \\
\hline
\end{tabular}

Abbreviation: PTPN12, tyrosine-protein phosphatase non-receptor type 12; NSCLC, non-small cell lung cancer; SCC, squamous cell carcinoma.

${ }^{\mathrm{a}} \chi^{2}$ test;

${ }^{\mathrm{b}}$ Median age;

c Non-SCC includes adenocarcinoma, adenosquamous carcinoma, anaplastic largecell carcinoma, sarcoma, adenoid cystic carcinoma, mucoepidermoid carcinoma and carcinoid tumor. 


\section{Immunohistochemical assessment of PTPN12 Expression}

Figure 2 showed that PTPN12 was localized to the cytoplasm. Using the criteria described above, of the 215 tumors, 106 (49.3\%) were PTPN12-high expression, and 109 (50.7\%) were PTPN12-low expression. Table 1 compared the clinicopathological parameters according to the expressive level of PTPN12. $\chi^{2}$ test showed that the PTPN12 expression was closely correlated with visceral pleural invasion $(\mathrm{p}=0.038$, less common in the presence than in the absence of visceral pleural invasion), and pTNM stage ( $p=0.038$, less common in pTNM stage II and III patients than pTNM stage I patients).

\section{PTPN12 expression and survival}

The median follow-up period was 46 months with 89 alive and 126 cancer-related deaths at the last clinical follow-up. The 1-, 3-, 5-year survival rates for the entire cohort of patients were $69 \%, 49 \%$, and $39 \%$, respectively.

In the Kaplan-Meier analysis, PTPN12 expression was significantly associated with DFS and OS. For the whole cohort, median DFS was longer in patients with high-PTPN12 expression than those with low-PTPN12 expression $(\mathrm{p}<0.001)$. Median OS among patients with PTPN12-high tumors was also longer than those with PTPN12-low tumors $(\mathrm{p}<0.001)$. Furthermore, we examined the relationship between PTPN12 expression and survival based upon histology subgroup. We observed a significant different in both DFS and OS durations in non-SCC patients with high or low-PTPN12 expression (DFS: 32 vs. 11 months, $\mathrm{p}<0.001$; OS: 63 vs. 24 months, $\mathrm{p}<0.001$ ), whereas OS durations were similar between high and low-PTPN12 expression subsets in patients with SCC (57 vs. 46 months, $\mathrm{p}=0.094$ ). Details were showed in Table 2 and Figure 3.

To determine whether PTPN12 expression could serve as an independent prognostic parameter, we examined DFS and OS using the Cox proportional hazards model. The results revealed that pTNM stage (DFS: $\mathrm{p}<0.001$; OS: $\mathrm{p}<0.001)$ and PTPN12 expression (DFS: $\mathrm{p}<0.001$; OS: $\mathrm{p}<0.001)$ were independent, significant predictors for DFS and OS. Interestingly, when we carried out the multivariate analyses in each histology subgroup, the benefit of high-PTPN12 expression was especially

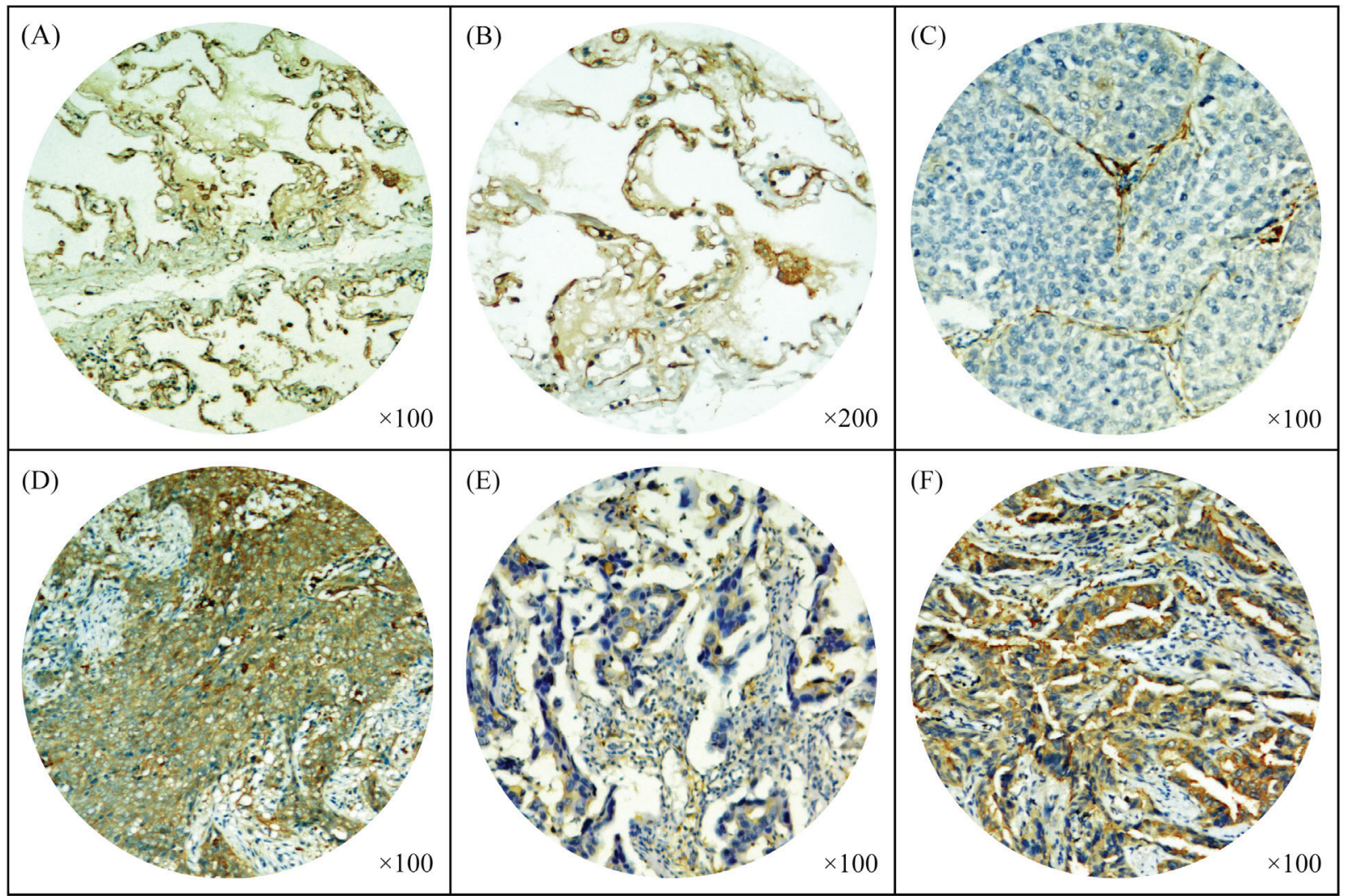

Figure 2: Immunohistochemical staining of tyrosine-protein phosphatase non-receptor type 12 (PTPN12) in paracancerous normal lung tissues and non-small cell lung cancer (NSCLC) tissues. (A-B) Expression of PTPN12 in paracancerous normal lung tissues; (C-F) Expression of PTPN12 in squamous cell carcinoma (SCC) and adenocarcinoma (ADC): (C) A PTPN12-low expressive SCC tissue and (D) a PTPN12-high expressive SCC tissue; (E) A PTPN12-low expressive ADC tissue and (F) a PTPN12-high expressive ADC tissue. 
(A)

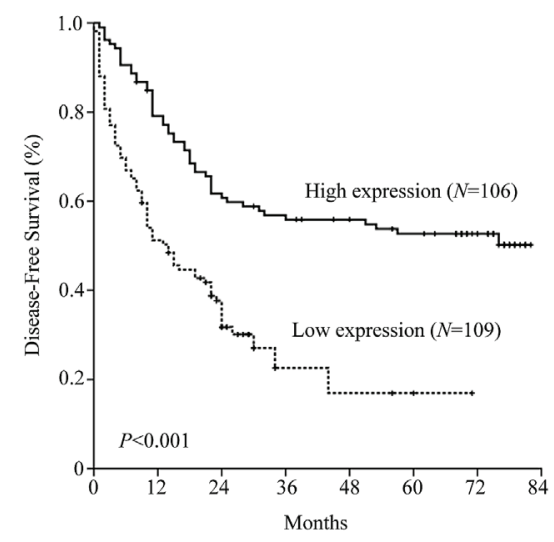

No. at risk

$\begin{array}{lllllllll}\text { High expression } & 106 & 82 & 64 & 58 & 54 & 49 & 31 & 0\end{array}$

$\begin{array}{llllllll}\text { Low expression } & 109 & 55 & 32 & 4 & 3 & 2 & 0\end{array}$

(C)

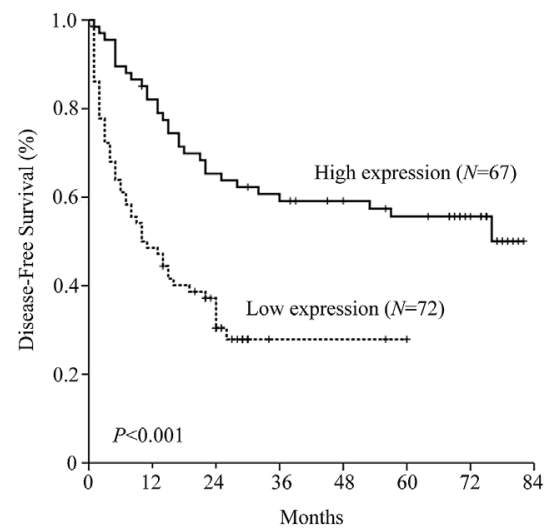

No. at risk

$\begin{array}{lllllllll}\text { High expression } & 67 & 54 & 43 & 39 & 35 & 31 & 16 & 0\end{array}$

$\begin{array}{llllllll}\text { Low expression } & 72 & 35 & 22 & 2 & 2 & 1 & 0\end{array}$

(E)

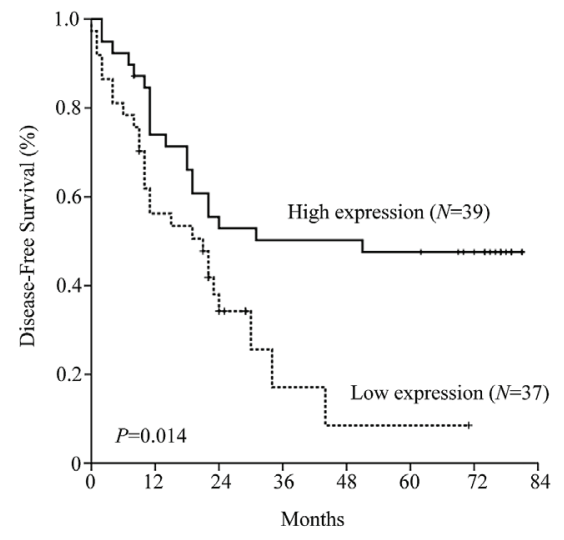

No. at risk

$\begin{array}{lllllllll}\text { High expression } & 39 & 28 & 21 & 19 & 19 & 18 & 15 & 0\end{array}$

Low expression
(B)

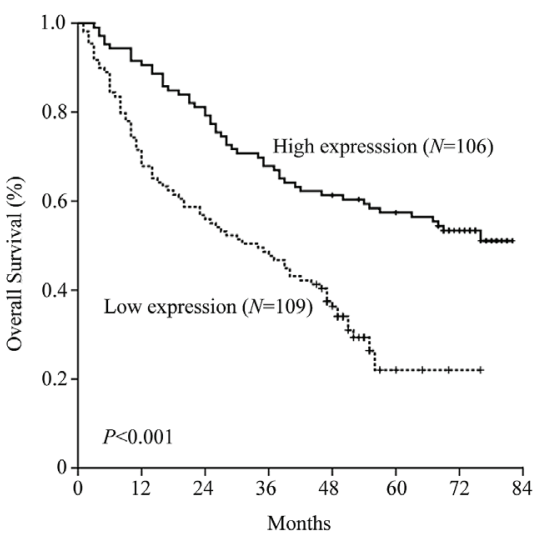

No. at risk

$\begin{array}{lllllllll}\text { High expression } & 106 & 97 & 86 & 72 & 65 & 59 & 37 & 0\end{array}$ $\begin{array}{lllllllll}\text { Low expression } & 109 & 78 & 62 & 53 & 34 & 4 & 1 & 0\end{array}$

(D)

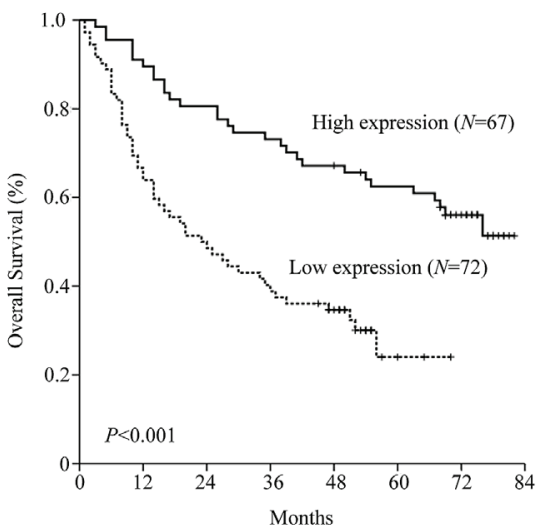

No. at risk

$\begin{array}{lllllllll}\text { High expression } & 67 & 61 & 54 & 49 & 45 & 40 & 21 & 0\end{array}$ $\begin{array}{llllllll}\text { Low expression } & 72 & 48 & 36 & 29 & 22 & 3 & 0\end{array}$

(F)

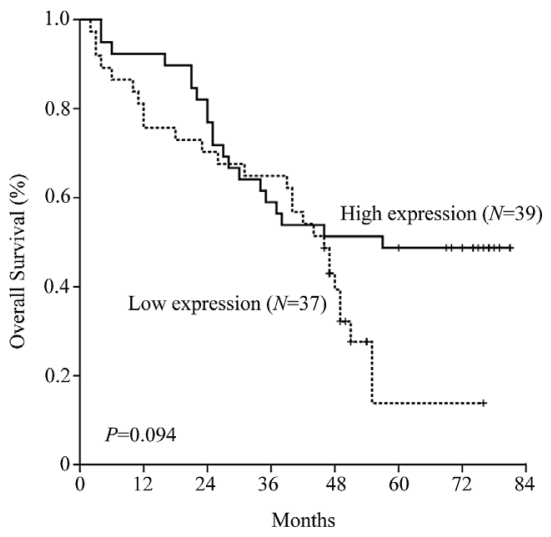

No. at risk

$\begin{array}{lrrrrrrrr}\text { High expression } & 39 & 36 & 32 & 23 & 20 & 19 & 16 & 0 \\ \text { Low expression } & 37 & 30 & 26 & 24 & 12 & 1 & 1 & 0\end{array}$

Figure 3: Kaplan-Meier estimates of the probability of survival in patients with non-small cell lung cancer (NSCLC). (A) Disease-free survival (DFS) and (B) overall survival (OS) curves for the whole cohort of patients with NSCLC; (C) DFS and (D) OS curves for the non-squamous cell carcinoma (non-SCC) patients; (E) DFS and (F) OS curves for the SCC patients. 
Table 2: Prognostic significance of PTPN12 expression in patients with NSCLC

\begin{tabular}{|c|c|c|c|c|c|c|c|}
\hline \multirow{2}{*}{$\begin{array}{l}\text { PTPN12 } \\
\text { Expression }\end{array}$} & \multirow{2}{*}{$\begin{array}{l}\text { Number of } \\
\text { Patients }\end{array}$} & \multicolumn{3}{|c|}{ Disease-Free Survival } & \multicolumn{3}{|c|}{ Overall Survival } \\
\hline & & Mean & Median & \multirow{2}{*}{$\frac{\text { p Value }^{\mathbf{a}}}{<0.001}$} & Mean & Median & \multirow{2}{*}{$\begin{array}{c}\text { p Value }^{\mathbf{a}} \\
<0.001\end{array}$} \\
\hline Total & & & & & & & \\
\hline Low expression & 109 & 23.5 & 14.0 & & 36.1 & 34.0 & \\
\hline High expression & 106 & 51.0 & NR & & 57.1 & NR & \\
\hline \multicolumn{8}{|l|}{ Histology } \\
\hline SCC & & & & 0.014 & & & 0.094 \\
\hline Low expression & 37 & 22.7 & 21.0 & & 39.5 & 46.0 & \\
\hline High expression & 39 & 46.8 & 51.0 & & 52.9 & 57.0 & \\
\hline Non-SCC & & & & $<0.001$ & & & $<0.001$ \\
\hline Low expression & 72 & 22.9 & 10.0 & & 32.5 & 23.0 & \\
\hline High expression & 67 & 53.0 & 10 & & 59.3 & NR & \\
\hline \multicolumn{8}{|c|}{$\begin{array}{l}\text { Abbreviation: PTPN12, tyrosine-protein phosphatase non-receptor type 12; NSCLC, non-small cell lung cancer; SCC, squamous cell carcinoma; } \\
\text { ADC, adenocarcinoma; NR, not reach; pT status, pathological tumor; pN status, pathological node; pTNM stage, pathological tumor-node- } \\
\text { metastasis stage. }\end{array}$} \\
\hline \multirow[b]{2}{*}{ Cohort } & \multirow{2}{*}{\multicolumn{2}{|c|}{ Variables }} & Disease-Free Survival & & \multirow{2}{*}{\multicolumn{2}{|c|}{ Overall Survival }} & \\
\hline & & & HR $(95 \% \mathrm{CI})$ & p Value ${ }^{a}$ & & & p Value ${ }^{\text {a }}$ \\
\hline \multirow[t]{7}{*}{ All population } & pTNM Stage & & & $<0.001$ & & & $<0.001$ \\
\hline & Stage I & & Reference & & & & \\
\hline & Stage II & & $3.148(1.950-5.083)$ & & & $-4.737)$ & \\
\hline & Stage III & & $4.834(2.998-7.796)$ & & & $-7.048)$ & \\
\hline & PTPN12 expre & sion & & $<0.001$ & & & $<0.001$ \\
\hline & Low & & $2.352(1.609-3.438)$ & & & $-3.084)$ & \\
\hline & High & & Reference & & & & \\
\hline \multirow[t]{7}{*}{$\mathrm{SCC}$} & pTNM Stage & & & 0.014 & & & 0.009 \\
\hline & Stage I & & Reference & & & & \\
\hline & Stage II & & $1.751(0.852-3.595)$ & & & $-3.385)$ & \\
\hline & Stage III & & $3.068(1.449-6.495)$ & & & $-6.856)$ & \\
\hline & PTPN12 expre & sion & & 0.056 & & & 0.104 \\
\hline & Low & & $1.200(0.915-3.049)$ & & & $-3.015)$ & \\
\hline & High & & Reference & & & & \\
\hline \multirow[t]{7}{*}{ Non-SCC } & pTNM Stage & & & $<0.001$ & & & $<0.001$ \\
\hline & Stage I & & Reference & & & & \\
\hline & Stage II & & $4.909(2.548-9.458)$ & & & $-8.414)$ & \\
\hline & Stage III & & $6.320(3.334-11.980)$ & & & $-10.142)$ & \\
\hline & PTPN12 expre & sion & & $<0.001$ & & & $<0.001$ \\
\hline & Low & & $2.337(1.438-3.798)$ & & & $-3.830)$ & \\
\hline & High & & Reference & & & & \\
\hline
\end{tabular}

Abbreviation: PTPN12, tyrosine-protein phosphatase non-receptor type 12; NSCLC, non-small cell lung cancer; SCC, squamous cell carcinoma; $\mathrm{HR}$, hazard ratio; $95 \% \mathrm{CI}, 95 \%$ confidence index.

${ }^{\text {a }}$ Cox proportional hazards model.

significant in non-SCC patients (DFS: $\mathrm{p}<0.001$; OS: $\mathrm{p}<0.001)$. The details are presented in Table 3 .

\section{DISCUSSION}

Belonging to the PTPs family, PTPN12 is an enzyme that in humans is encoded by the PTPN12 gene [13]. PTPN12 are known to be signaling molecules that regulate a variety of cellular processes $[8,9,14,15]$. Researchers have recently suggested that PTPN12 may also be involved in the human carcinogenesis. For this reason, based on unique etiology, patient characteristics, uniform treatment modalities and long-term follow-up, the current study is the first to evaluate the expression and potential implications of PTPN12 in NSCLC patients. Notably, we observed that PTPN12 expression correlated significantly with visceral pleural invasion and pTNM stage. Most importantly, survival durations were significantly longer among patients with high-PTPN12 expression than among patients with low-PTPN12 expression. In the histology subgroup analyses, we observed that the survival benefit of high-PTPN12 expression might be limited in non-SCC patients. Our findings indicated that PTPN12 might act as a tumor suppressor and serve as a potential predictive biomarker for NSCLC patients, especially for those with non-SCC.

Some previous studies have reported that PTPs, including PTPN12, regulate the equilibrium of tyrosine phosphorylation and play a prominent role in tumor suppression [8-10, 16, 17]. Emma et al. demonstrated that PTPN12 silencing enhances cell migration in ovarian cancer SKOV-3 cells, through focal adhesion kinase (FAK, a focal adhesion-associated protein kinase involved in cellular adhesion and spreading processes, and it often up-regulated in cancer cells [18-20] phosphorylation at Y397 [21]. Recently, Emma et al. carried out a laboratory investigation and found that silenced PTPN12 depressed 
phosphatase and tensin homolog (PTEN) expression [22]. PTEN negatively regulates intracellular levels of phosphatidylinositol-3, 4, 5-trisphosphate in cells and functions as a tumor suppressor by negatively regulating PI3K/AKT signaling pathway [23-25]. This, in turn, contributes to suppress cell migration, through activation of GSK3 (target pS21-GSK3 $\alpha$ ) (GSK3, a substrate of $\mathrm{AKT}$, a kinase regulating a number of diverse functions, including metabolism, cell cycle, cell migration and oncogenesis [26-28] and inhibition of FAK (target pS722) [22]. Furthermore, in the breast tumor MDA-MB-231 cells, PTPN12 silencing enhanced cell proliferation (unpublished results). Most of these findings support the function of PTPN12 as a tumor suppressor.

Recently, the study of Sun et al. demonstrated that loss of PTPN12 leads to morphogenesis and malignant transformation in mammary epithelial cells [12]. Interestingly, in breast cancer cells with loss of PTPN12 expression, restoring PTPN12 expression suppresses proliferation, tumorigenesis and metastasis. As well as, lung cells collected from dox-inducible PTPN12 cDNA animals present significantly fewer metastases than dox-free animals (termed MDA-MB231-LM2 cells, a highly tumorigenic and metastatic subpopulation of MDA-MB231 [29, 30]. Collectively, Sun et al. have discovered a promising and extensive network of negative regulation with alternation oncogenes and tumor suppressors consisting of $\beta$-TRCP, REST, miR-214, and PTPN12, which inhibit RTKs to control cell proliferation, tumorigenesis, and survival.

Because of the crucial roles of PTPN12 in tumorigenesis, its potential application in the clinic has been evaluated. Along with pTNM stage, the expressive level of PTPN12 was shown to be an independent and significant prognostic parameter in resectable NSCLCs. Our previous investigation recently demonstrated significantly longer survival durations in esophageal cancer patients with high PTPN12 expression than those with low PTPN12 expression [31]. Although the population of our previous study limited to squamous cell carcinoma, our results suggested that PTPN12 might be served as a clinical predictive biomarker for various cancer populations. Wu et al. indicated that low PTPN12 expression is associated with poor prognosis and may be used as a potential prognostic variable in triple-negative breast cancer [32]. These findings were consistent with the present study showing a favorable prognostic impact of high PTPN12 expression.

We observed that the benefit of high-PTPN12 expression was especially significant in non-SCC patients. One explanation for this finding may be via inhibition of multiple RTKs. Adenocarcinoma, a subset of NSCLCs, have been shown to harbor activating mutations in the epidermal growth factor receptor gene (EGFR), such cancers are responsive to gefitinib, a specific inhibitor of the tyrosine kinase activity of EGFR. Sun and colleagues have indicated that PTPN12 suppresses tumorigenesis by inhibiting multiple RTKs. This is consistent with our study and illustrates a special role of PTPN12 according to histological type.

We acknowledged the limitations of the present retrospective analysis. Firstly, we did not examine the expressive level of the upstream and downstream effectors of PTPN12, which could provide accurate evidence of the functional status of PTPN12, further refine the prognostic role of this biomarker and potentially facilitate the establishment of patient-tailored medical strategies and supports. Secondly, our study population was composed of Chinese population, which somewhat limits the generalizability of our results. Accordingly, the results of further investigations including more diverse populations (white/black/brown participants) from other institutes are needed to confirm our findings. In addition, our study is a retrospective study, relied exclusively on a singleinstitutional database. In the future, we plan to expand the prospective analyses to include upstream and downstream effectors of PTPN12 in the samples of multi-institution, and results will be reported in future publications.

In conclusion, this is the first study to show that patients with completely resected NSCLCs and PTPN12 high expression tumors had favorable survival durations compared to that of patients with low PTPN12 expression. Our findings demonstrate that determination of PTPN12 expression in NSCLCs after radical operation can contribute as an independent predictor of patient survival. Further mechanistic studies will be vital to facilitate our understanding of PTPN12 functional role in NSCLC.

\section{PATIENTS AND METHODS}

\section{Patients and treatment}

From April 2002 and March 2005, at Sun Yat-Sen University Cancer Center, 240 patients with complete surgical resection (R0) for NSCLC were eligible for our study. Pretreatment evaluation included complete history and a physical examination, complete blood cell count, serum biochemistry, chest X-ray, computed tomography (CT) scans of the chest and abdomen, and bronchoscopy. Whole-body bones scan and magnetic resonance imaging (MRI) scan of brain were used to exclude possible metastasis. Patients who had previous malignant disease, a second primary tumor, suspected distant metastasis, non-curative resection (R1), died of postoperative complications/non-cancer related death and lost follow-up were excluded. All cases underwent complete resection of lung cancer with mediastinal lymph node dissection. Adjuvant chemotherapy (cisplatin-based combinations) was performed in patients with stage II and stage III disease if the patients could tolerate treatment 
after curative-intent surgery, or unless the patients refused adjuvant chemotherapy. Patients with stage III disease and pathologic evidence of N2 disease received postoperative mediastinal radiotherapy. Tumor differentiation grades were defined according to the World Health Organization criteria. Stage was recorded based on AJCC (2009) [33]. The study was approved by the medical ethics committee of the Cancer Center at Sun Yat-Sen University.

After completion of primary treatment, patients were followed up every 4-6 months in the first 3 years and every 12 months thereafter. The survival status was verified again using the best available methods in May 2010, including verifying the clinical attendance records and with direct telecommunication with the patient or their family.

\section{Construction of the tissue microarray}

The tissue microarray was constructed according to methods described previously [34]. The tissues (240 NSCLC tissues and 50 paracancerous normal lung tissues) from the tumor bank were collected, fixed in ethanol, and embedded in paraffin [the paracancerous normal samples were obtained from the lung tissues which were: (1) $2 \mathrm{~cm}$ or more; or (2) the size of the nodule or more from tumor margins; there was no microscopic residual tumor cells]. Hematoxylin and eosin-stained sections from a single random block from each patient were reviewed by a senior pathologist (Rong-Zhen Luo) to define representative tumor regions. Two targeted core samples of each specimen were obtained using a tissue array instrument (MiniCore instruments; Alphelys, Plaisir, France). Briefly, 10-mm tissue cylinders were punched and arrayed on a recipient paraffin block. Sections $(5 \mu \mathrm{m})$ of the tissue array (recipient) block were cut and placed on glass slides.

\section{Western blot}

Total proteins were extracted with $1 \times$ SDS sample buffer [62.5 mmol/L Tris-HCl (pH 6.8), 2\% SDS, 10\% glycerol, and 5\% 2-mercaptoethanol]. The protein concentration was determined using the Bradford assay (Bio-Rad Laboratories, Hercules, CA). A total of $20 \mu \mathrm{g}$ protein was electrophoretically separated in $12 \%$ SDS polyacrylamide gels and transferred onto polyvinylidene difluoride membranes (Amersham Pharmacia Biotech, Piscataway, NJ). Anti-PTPN12 rabbit polyclonal (1:500, HPA007097, Prestige Antibodies, Atlas Antibodies, Sigma, more details: http://www.proteinatlas.org/ ENSG00000127947-PTPN12/cancer) and anti-rabbit (1:2000, Santa Cruz Biotechnology, Santa Cruz, CA) antibodies were used to detect PTPN12 protein. Anti$\alpha$-tubulin mouse monoclonal (1:2000, Sigma) and antimouse (1:2000, Santa Cruz Biotechnology, Santa Cruz, CA) antibodies were used to confirm equal loading. The
Western blot bands were scanned and analyzed by the Quantity One program (Bio-Rad, Hercules, CA).

\section{Immunohistochemistry}

A standard protocol for the immunostaining of tissue microarray sections was used. In brief, tissue microarray sections were rehydrated through graded alcohol. Endogenous peroxidase activity was blocked with $0.3 \%$ hydrogen peroxide for $15 \mathrm{~min}$. For epitope retrieval, the tissue microarray slides were exposed to $10 \mathrm{mM}$ citrate buffer ( $\mathrm{pH} \mathrm{6.0)}$ ) and heated for $5 \mathrm{~min}$. The tissue microarray slides were incubated with antiPTPN12 antibody at a dilution of 1:50 (HPA007097, 100 $\mu 1$, Prestige Antibodies, Atlas Antibodies, Sigma, more details: http://www.proteinatlas.org/ENSG00000127947PTPN12/cancer) for 12 hours at $4^{\circ} \mathrm{C}$ in a moist chamber. Subsequently, biotinylated secondary antibody was applied for $30 \mathrm{~min}$ at $37^{\circ} \mathrm{C}$. Then, the sections were incubated with streptavidin-horseradish peroxidase complex and developed with 3-diaminobenzidine tetrahydrochloride (DAB). Mayer's hematoxylin was applied as a counterstain. PTPN12 immunopositive breast cancer slides were used as a positive control. As a negative control, the primary antibody was replaced by normal rabbit serum.

Cytoplasmic PTPN12 was evaluated according to the percentage of positively stained cells (median, 60\%; range, $0-100 \%$ ) and staining intensity (negative staining; low staining: light yellow; intermediate staining: yellow brown; and high staining: brown). PTPN12 expression index: 0 : negative; $1: \leq 60 \%$ of cells positive with low intensity; $2:>60 \%$ of cells positive with low intensity or $\leq 60 \%$ with intermediate intensity; $3:>60 \%$ of cells positive with intermediate intensity or $\leq 60 \%$ of cells positive with high intensity; and $4:>60 \%$ of cells positive with high intensity. For PTPN12, the expression index of the paracancerous normal lung tissues was 2 to 4 . Thus, we defined an expression index of 0 and 1 as the low expression, while an expression index of 2-4 was considered high expression.

Two investigators who were unaware of the clinicopathological data independently evaluated PTPN12 staining under a light microscope. In this study, a minimum of 300 epithelial cells was counted for each normal or tumor case. In order to reach a conclusive judgment, discordant cases were reviewed.

\section{Statistical analysis}

The statistical analyses were performed using the SPSS 13.0 software package (SPSS, Inc., Chicago, IL). Disease-free survival (DFS) and overall survival (OS) were defined as the time from the date of surgery to the date of regional recurrence or distant metastasis and death 
or final clinical follow-up, respectively. The correlation between PTPN12 and clinicopathological characteristics was assessed using the $\chi^{2}$ test. Multivariate Cox regression analysis was performed for all parameters that were found to be significant by the univariate analysis. Actuarial survival rates were plotted against time using the KaplanMeier method, and log-rank testing was used to compare the differences between the curves. Two- sided $p<0.05$ was considered statistically significant.

\section{ACKNOWLEDGMENTS}

This work was supported by The Nature Science Foundation of China (Grant number: 81372568) and The Science and Technology Project of Guangdong Province of China (Grant number: 2010B031600315).

The study was approved by the medical ethics committee of Sun Yat-Sen University Cancer Center.

\section{REFERENCES}

1. Siegel R, Naishadham D and Jemal A. Cancer statistics, 2013. CA Cancer J Clin. 2013; 63:11-30.

2. Teeter SM, Holmes FF and McFarlane MJ. Lung carcinoma in the elderly population. Influence of histology on the inverse relationship of stage to age. Cancer. 1987; 60:13311336.

3. Soes S, Daugaard IL, Sorensen BS, Carus A, Mattheisen M, Alsner J, Overgaard J, Hager H, Hansen LL and Kristensen LS. Hypomethylation and increased expression of the putative oncogene ELMO3 are associated with lung cancer development and metastases formation. Oncoscience. 2014; 1:367-374.

4. Tomida S, Koshikawa K, Yatabe Y, Harano T, Ogura N, Mitsudomi T, Some M, Yanagisawa K, Takahashi T and Osada H. Gene expression-based, individualized outcome prediction for surgically treated lung cancer patients. Oncogene. 2004; 23:5360-5370.

5. Okamura K, Takayama K, Kawahara K, Harada T, Nishio M, Otsubo K, Ijichi K, Kohno M, Iwama E, Fujii A, Ota K, Koga T, Okamoto T, et al. PICT1 expression is a poor prognostic factor in non-small cell lung cancer. Oncoscience. 2014; 1:375-382.

6. Cheng YJ, Lee YC, Chiu WC, Tsai JW, Su YH, Hung AC, Chang PC, Huang CJ, Chai CY and Yuan SS. High Id1 expression, a generally negative prognostic factor, paradoxically predicts a favorable prognosis for adjuvant paclitaxel plus cisplatin therapy in surgically treated lung cancer patients. Oncotarget. 2014; 5:11564-11575.

7. O'Shannessy DJ, Yu G, Smale R, Fu YS, Singhal S, Thiel RP, Somers EB and Vachani A. Folate receptor alpha expression in lung cancer: diagnostic and prognostic significance. Oncotarget. 2012; 3:414-425.

8. Hunter T. Tyrosine phosphorylation: thirty years and counting. Curr Opin Cell Biol. 2009; 21:140-146.
9. Yarden $\mathrm{Y}$ and Sliwkowski MX. Untangling the ErbB signalling network. Nat Rev Mol Cell Biol. 2001; 2:127137.

10. Tonks NK. Protein tyrosine phosphatases: from genes, to function, to disease. Nat Rev Mol Cell Biol. 2006; 7:833846.

11. Hsu JL, Huang SY, Chow NH and Chen SH. Stable-isotope dimethyl labeling for quantitative proteomics. Anal Chem. 2003; 75:6843-6852.

12. Sun T, Aceto N, Meerbrey KL, Kessler JD, Zhou C, Migliaccio I, Nguyen DX, Pavlova NN, Botero M, Huang J, Bernardi RJ, Schmitt E, Hu G, et al. Activation of multiple proto-oncogenic tyrosine kinases in breast cancer via loss of the PTPN12 phosphatase. Cell. 2011; 144:703-718.

13. Takekawa M, Itoh F, Hinoda Y, Adachi M, Ariyama T, Inazawa J, Imai $\mathrm{K}$ and Yachi A. Chromosomal localization of the protein tyrosine phosphatase G1 gene and characterization of the aberrant transcripts in human colon cancer cells. FEBS Lett. 1994; 339:222-228.

14. Angers-Loustau A, Cote JF and Tremblay ML. Roles of protein tyrosine phosphatases in cell migration and adhesion. Biochem Cell Biol. 1999; 77:493-505.

15. Espejo R, Rengifo-Cam W, Schaller MD, Evers BM and Sastry SK. PTP-PEST controls motility, adherens junction assembly, and Rho GTPase activity in colon cancer cells. Am J Physiol Cell Physiol. 2010; 299:C454-463.

16. Streit S, Ruhe JE, Knyazev P, Knyazeva T, Iacobelli S, Peter S, Hoefler H and Ullrich A. PTP-PEST phosphatase variations in human cancer. Cancer Genet Cytogenet. 2006; 170:48-53.

17. Wang Z, Shen D, Parsons DW, Bardelli A, Sager J, Szabo S, Ptak J, Silliman N, Peters BA, van der Heijden MS, Parmigiani G, Yan H, Wang TL, et al. Mutational analysis of the tyrosine phosphatome in colorectal cancers. Science. 2004; 304:1164-1166.

18. Andre $\mathrm{E}$ and Becker-Andre $\mathrm{M}$. Expression of an $\mathrm{N}$-terminally truncated form of human focal adhesion kinase in brain. Biochem Biophys Res Commun. 1993; 190:140-147.

19. Lackie JM and Blackshaw SE. (2007). The dictionary of cell and molecular biology. (Amsterdam ; Boston: Academic Press).

20. Serrels A, McLeod K, Canel M, Kinnaird A, Graham K, Frame MC and Brunton VG. The role of focal adhesion kinase catalytic activity on the proliferation and migration of squamous cell carcinoma cells. Int J Cancer. 2012; 131:287-297.

21. Villa-Moruzzi E. Tyrosine phosphatases in the HER2directed motility of ovarian cancer cells: Involvement of PTPN12, ERK5 and FAK. Anal Cell Pathol (Amst). 2011; 34:101-112.

22. Villa-Moruzzi E. PTPN12 controls PTEN and the AKT signalling to FAK and HER2 in migrating ovarian cancer cells. Mol Cell Biochem. 2013; 375:151-157. 
23. Salmena L, Carracedo A and Pandolfi PP. Tenets of PTEN tumor suppression. Cell. 2008; 133:403-414.

24. Shih MC, Chen JY, Wu YC, Jan YH, Yang BM, Lu PJ, Cheng HC, Huang MS, Yang CJ, Hsiao M and Lai JM. TOPK/PBK promotes cell migration via modulation of the PI3K/PTEN/AKT pathway and is associated with poor prognosis in lung cancer. Oncogene. 2012; 31:2389-2400.

25. Chu EC and Tarnawski AS. PTEN regulatory functions in tumor suppression and cell biology. Med Sci Monit. 2004; 10:RA235-241

26. Rayasam GV, Tulasi VK, Sodhi R, Davis JA and Ray A. Glycogen synthase kinase 3: more than a namesake. Br J Pharmacol. 2009; 156:885-898.

27. Bianchi M, De Lucchini S, Marin O, Turner DL, Hanks SK and Villa-Moruzzi E. Regulation of FAK Ser-722 phosphorylation and kinase activity by GSK3 and PP1 during cell spreading and migration. Biochem J. 2005; 391:359-370.

28. Kotliarova S, Pastorino S, Kovell LC, Kotliarov Y, Song H, Zhang W, Bailey R, Maric D, Zenklusen JC, Lee J and Fine HA. Glycogen synthase kinase-3 inhibition induces glioma cell death through c-MYC, nuclear factor-kappaB, and glucose regulation. Cancer Res. 2008; 68:6643-6651.

29. Minn AJ, Gupta GP, Siegel PM, Bos PD, Shu W, Giri DD, Viale A, Olshen AB, Gerald WL and Massague J. Genes that mediate breast cancer metastasis to lung. Nature. 2005; 436:518-524.

30. Meerbrey KL, Hu G, Kessler JD, Roarty K, Li MZ, Fang JE, Herschkowitz JI, Burrows AE, Ciccia A, Sun T, Schmitt EM, Bernardi RJ, Fu X, et al. The pINDUCER lentiviral toolkit for inducible RNA interference in vitro and in vivo. Proc Natl Acad Sci U S A. 2011; 108:3665-3670.

31. Cao X, Li Y, Luo RZ, He LR, Yang J, Zeng MS and Wen ZS. Tyrosine-protein phosphatase nonreceptor type 12 is a novel prognostic biomarker for esophageal squamous cell carcinoma. Ann Thorac Surg. 2012; 93:1674-1680.

32. Wu MQ, Hu P, Gao J, Wei WD, Xiao XS, Tang HL, Li X, Ge QD, Jia WH, Liu RB and Xie XM. Low Expression of Tyrosine-protein Phosphatase Nonreceptor Type 12 is Associated with Lymph Node Metastasis and Poor Prognosis in Operable Triple-negative Breast Cancer. Asian Pac J Cancer Prev. 2013; 14:287-292.

33. Sobin L GM, Wittekind C, eds. (2009.). TNM Classification of malignant tumors. 7th ed. (Hoboken, NJ: John Wiley \& Sons, Inc.).

34. Kononen J, Bubendorf L, Kallioniemi A, Barlund M, Schraml P, Leighton S, Torhorst J, Mihatsch MJ, Sauter $G$ and Kallioniemi OP. Tissue microarrays for highthroughput molecular profiling of tumor specimens. Nat Med. 1998; 4:844-847. 